\title{
85
}

\section{Turning the Tables: Antisemitic Discourse in Post-War Austria}

\author{
Ruth Wodak
}

It would be absurd to deny that many Austrians responded to some extent to the Nazis' racial propaganda; however, when they saw how antisemitism was actually put into practice, they were cured. One could safely say that sympathy for the persecuted Jews eradicated antisemitism in Austria. I do not believe that this issue will ever again assume even the slightest importance (Leopold Figl, the first elected Federal Chancellor of the Austrian Second Republic). ${ }^{1}$

[The international press] is dominated by the World Jewish Congress. This is well-known (Kurt Waldheim). ${ }^{2}$

$\mathrm{I}$

$\mathrm{f}$ it had been meant seriously, the Austrian Chancellor's optimism after 1945 was unfounded. In fact, Figl must have known better, since he had been present at meetings of the Council of Ministers immediately after 1945, where antisemitic sentiments were expressed by some other members of the government in conjunction with the debate about reparations payments to Austrian Jews who had survived the Shoa (see Knight, 1988). Figl's disingenuous remark can thus be regarded as but a further element designed to buttress Austria's positive image in the world.

Almost forty years later, public discourse about Jews in Austria in the course of the 'Waldheim affair' recalled earlier times and gave rise to a great deal of concern in the Jewish community organization (Gemeinde). ${ }^{3}$ The immediate occasion for this was the criticism which Jewish organizations, among others, directed against Kurt Waldheim, then campaigning for the Austrian presidency, and his hitherto hidden past. The Waldheim affair has exposed the tenuousness of official Austria's post-war Lebenslüge about the widespread complicity of

Source: Discourse E Society, vol. 2, no. 1, 1991, pp. 65-83. 
Austrians in the Nazi abomination, and the attendant denials of the existence of antisemitic prejudice in the post-war period this entailed (see Gruber and de Cillia, 1989; Wodak 1989a, 1990a, b, c; Wodak and de Cillia, 1988).

On the one hand, after 1945 the open expression of anti-Jewish hostility is subject to a public political taboo. Instead, one enumerates the Jewish friends one has or praises those Jews who contributed so much to Austrian culture (the standard 'philo-Semitic' discourse; cf. Stern, 1989). On the other hand, one expresses despair at not being allowed to criticize individual Jews. These predominantly foreign Jews are described as 'dishonourable' or worse, and they stand as representatives for Jews as a whole.

Within the limited scope of this paper, it is impossible to consider all aspects of the question of who speaks or writes in an antisemitic way for or to whom in what form and to what effect. ${ }^{4}$ I therefore begin with a brief sketch of the historicalsociological context of post-war antisemitism in Austria and indicate the register (both in terms of form and content) of antisemitic prejudice currently possible in contemporary Austria.

\section{A New Antisemitism in Austria?}

The Austrian sociologist Bernd Marin (Bunzl and Marin, 1983) has characterized antisemitism in Austria after 1945 as an 'antisemitism without Jews', since Jews constitute only. ${ }^{1}$ percent of the Austrian population (in Vienna, .5 percent). Moreover, antisemitism is stronger in those areas where Jews no longer live and where previously practically no Jews had lived, and among people who neither have had nor have any personal contact with Jews. In addition, according to Marin, it is an 'antisemitism without antisemites', since prejudice against Jews has been publicly forbidden and tabooed. Nevertheless, there is still 'antisemitism in polities'.

Whatever general validity Marin's thesis had prior to 1986, the results of our study suggest that Marin's findings are applicable to the period since then only with significant modifications.

The taboo against open expressions of explicitly antisemitic beliefs, for example, which Marin posited in an abstract form, has remained, but the means of circumventing it linguistically have extended its boundaries in such a way that the taboo itself appears to have lost some of its significance. Anti-Jewish prejudices which had remained hidden began to surface and were increasingly found in public settings. Quantitative sociological studies (Bunzl and Marin, 1983; Weiss, 1987; Kienzl and Gehmacher, 1987) ${ }^{5}$ have continually confirmed that a relatively high percentage of the Austrian population is open to antisemitic resentment.

The persistence of antisemitic attitudes is then ascribed to a small group of right-wing radicals. The number of such (radical) antisemites can thus be carefully delimited, and their numbers be shown to be falling. 'Antisemitism' is also frequently identified with a purely racial variety of anti-Jewish prejudice, which is equated with Nazism or with the Nazi extermination of the Jews, effectively 
excluding or minimizing other antisemitic traditions in Austria, such as the Christian or the Christian social traditions.

If one looks at the history of the political parties in the Austrian First Republic, for example, it is clear that the line dividing the different currents of antisemitism was indistinct. There has remained a reservoir of antisemitic prejudice from which, appropriately packaged, one could (and can) draw as occasion required. Since 1945, moreover, new motives for antisemitism have arisen. What the German Jewish author Henrik Broder said about the Germans is certainly applicable to the Austrians as well: they will never forgive the Jews for Auschwitz. The collapse of the Third Reich forced many, in Austria as in Germany, to confront the extent of the Nazi crimes. Doubts, guilt feelings, the need to justify or rationalize one's behaviour encouraged the development of strategies for 'dealing with the past': playing down the events themselves, denying all knowledge of them, transforming the victims into the causes of present woes (by not letting bygones be bygones, i.e. by simply continuing to exist). Moreover, since the Moscow Declaration ${ }^{6}$ offered Allied support to Austria's claim to have been (collectively) the first 'victim' of Hitlerite aggression, such reversals could draw upon an especially potent legitimation.

This putative victim status made it also possible to deny any responsibility which went beyond individual crimes; the new search for identity could produce a stronger feeling of nationalism, which in turn reinforced a specific definition of insiders and outsiders, of 'us' and 'them'.

Since 1945, there have been intermittent scandals involving antisemitic prejudice. In 1967, for example, the openly antisemitic outpourings of Thaddeus Borodajkiewicz, economics professor in Vienna, led to protests by both his opponents and supporters. At one of these, one of Borodajkiewicz's opponents was killed by the economic professor's neo-Nazi supporters. This was the occasion for a bi-partisan demonstration against political violence, but no corresponding campaign against his views. Borodajkiewicz himself was forced into early retirement (see Welzig, 1985). In the 1970 national assembly electoral campaign, posters of the candidate of the Austrian's People's Party for chancellor, Josef Klaus, emphasized that he, unlike his opponent Bruno Kreisky, whose Jewish origins were only too well known, was 'a genuine Austrian' (see Wodak and de Cillia, 1988). Simon Wiesenthal's publication in 1975 of material about the leader of the Freedom Party ${ }^{7}$ Friedrich Peter, ostensibly linking him to massacres carried out by the SS-unit to which he had belonged, was the occasion for a spate of public invective against Wiesenthal led by Bruno Kreisky. Kreisky insinuated, for example, that Wiesenthal had been a Gestapo informer. Another Kreisky comment, in an interview with a foreign journalist, 'if the Jews are a people, they are a lousy [mies] people', moreover, could in this context only serve to provide Jewish 'cover' for hostilities against Wiesenthal by those less schooled in the dialectical complexities of Kreisky's views. ${ }^{8}$ Against the wave of antisemitic hostilities unleashed by the events of 1986 , however, those prior scandals appear as minor affairs indeed.

Antisemitism in post-war Austria must therefore be viewed chiefly in relation to the various ways employed in dealing with alleged or real guilt, with alleged 
or actual accusations about the Nazi past. Both the large, traditional reservoir of antisemitic prejudice as well as a general, traditional discourse of collective experiences and attitudes provide discursive remedies, while several new topoi have been added. The forms of expression are very different, manifest or latent, explicit or very indirect. But each and every one appears to be a discourse of justification (or varieties of justification and defence).

\section{Antisemitic Stereotypes (Prejudice Content)}

Of the many clichés and contents of prejudice that are associated with Jews, we will only list the four that occurred most frequently in 1986 . We cannot deal in detail with the historical underpinnings of these prejudices, but refer readers to the literature as a source for the unusual features and uniqueness of the 'antisemitic syndrome' (see, inter alia, Adorno, 1973; Allport, 1987; Heinsohn, 1988; Poliakov, 1987; Pulzer, 1966; Wodak, 1990).

2.1 Christian antisemitism. According to this prejudice, Jews are regarded as the murderers of Christ, as traitors, Christian antisemitism was found especially in the mass media in 1986 (in the press and also in the semi-public sphere). These prejudices have the longest and most consistent history in Austria, being deeply embedded in the collective experience and in the 'collective subconscious' (Erdheim, 1984).

2.2 The 'dishonest' or 'dishonourable' Jew, the 'tricky Jew'. This prejudice has its origins in Judas' betrayal of Christ. On the other hand, this view is also based on economic stereotypes: in the Middle Ages Jews were responsible for lending money at interest (they were excluded from most other occupations). This cliché was used repeatedly with reference to the World Jewish Congress (WJC) in the course of the Waldheim debate in 1986.

2.3 The Jewish conspiracy. The Jews in the world dominate or control the international press, the banks, political power and capital, and they are planning the world conspiracy, e.g. the 'campaign' against Waldheim or against Austria (see Mitten, 1991; Wodak, 1990a). ${ }^{9}$

2.4 Jews are privileged. This new prejudice relates directly to the Holocaust. The Jews who 'emigrated' and thereby were able to avoid a far worse fate have no reason to complain. Emigration is not especially terrible, and Jews who were not in concentration camps have no grounds to be angry in any case.

\section{The 'Fear of Revenge'}

The collapse of the Third Reich in 1945 gave rise to several additional reasons for fearing the wrath of the 'vengeful Jew'. One was the fear of the discovery of war crimes and the persecution and conviction of war criminals. Another was the fear that the stolen ('aryanized') property could be demanded back. Finally, there was fear that the exiles would merely wish to return to their homeland. Not only would they possibly want their property back or take legal action 
against their former persecutors, but they might become dominant and again 'over-judaize' certain professions.

Feelings of guilt can be easily transformed into aggression towards those whose mere presence is an implicit 'attack'. One reacts defensively or by turning the tables on the victims themselves.

\section{Attack is the Best Defence: The Discourse of Justification}

There are various possible ways of dealing with or reacting to such an attack, be it real or imagined. We have distinguished macro-strategies, i.e. basic (conscious or unconscious, planned or spontaneous, or irrational) alternatives in social behaviour from the micro-strategies dependent on them (linguistic realizations). ${ }^{10}$

One reaction to perceived criticism is actually to deal openly with it, to show regret or remorse, to reappraise one's actions and accept blame in certain cases or qualify one's responsibility in others. This, however, rarely occurs, for such arguments usually take place in situations that are rife with conflict and pent-up emotions. And it is in these that the strategies we discovered become the means for transporting prejudice. One can attempt to impede the discussion, for example, or to ignore the situation (i.e. 'let sleeping dogs lie').

If this strategy does not work, the controversial event can be trivialized. In this way the persons involved, i.e. the perpetrators of these acts, are rendered harmless (i.e. there were not many, one does not know them, etc.), or a euphemism is employed to describe the acts themselves, for example in the use of 'emigration' to describe 'expulsion'. Such a trivialization can manifest itself in different ways, either by rationalization (i.e. there are really objective reasons for antisemitism); by accusing someone else (i. e. someone else is guilty, too); by shifting the blame (i.e. it was someone else's fault), by personalizing it (i.e. only one individual is to blame); or by depersonalizing it altogether (i.e. somebody was to blame), or by making fun of the accusations (i.e. the attackers exaggerate and dramatize them in an unacceptable way). Guilt as such is not, in principle, denied, but rather rendered meaningless.

Apart from merely shifting responsibility for events on to named or unnamed persons, the disavowal of personal knowledge or involvement can also involve a mechanism of victim-victimizer reversal, or the designation of a scapegoat in the case of group conflict (the enemy from the outside). In an argument among individuals, the blame can by mutual agreement be placed on someone who is not present. The defamation and debasement of the opponent belongs to this group of micro-strategies, since this makes blaming the victim, i.e. the victimvictimizer reversal, especially easy. In this case, possible feelings of guilt are transformed into aggression and into a counter-attack. This mechanism explains, for example, how the 'Kreisky-Peter-Wiesenthal affair' eventually became merely the 'Wiesenthal affair' (see Wodak et al., 1990).

Yet another alternative is to deny the guilt in principle. Accusations and attacks are distorted or invented and ascribed to opponents who had not made 
them, at least not in the form alleged. A systematic distortion of the facts takes place. One is thus justified in protecting oneself or planning counter-attacks against such 'infamous' attacks. In this way a second reality is constructed, a portrayal of an enemy against which every measure of defence is permissible.

\section{Anti-Jewish (Antisemitic) Language Use: The Pervasiveness of Antisemitic Prejudice in Public Life in Austria}

The degree of threat and hostility towards Jews expressed in language can vary greatly: different forms and different degrees of directness and boldness can be differentiated according to context and speaker. In analysing the material, four hierarchical levels of antisemitic statements were identified which correspond to the different individual strategies of justification. A connection can be seen between the content of prejudice, political context, setting, speaker and form of expression.

Level 1. Trivialization and relativization of antisemitism and the uniqueness of the Holocaust (putting the blame on someone else, generalizing). This occurred in totally formal and official contexts such as news broadcasts and informational programmes on Austrian radio and television. The issues of a world conspiracy and Christian issues dominate on this level.

Level 2. Statements with the content: 'antisemitism is the Jews' own fault' (victimvictimizer reversal). Such remarks are packaged differently (as direct accusations, as threats or as insinuations) and occur in many contexts, especially in semi-public ones (i.e. broadcast interviews or in TV discussions) and finally also in the memorial vigil (anonymous discussions on the street, in the centre of town, June 1987, due to a memorial vigil dedicated to the victims of World War II) (see Wodak, 1990a,b). Greed, dishonesty and vindictiveness constitute the contents of additional prejudice.

Level 3. All traditional antisemitic prejudices appear: (a) implicit (stories, allusions); or (b) explicit (generalizations). This requires either less formal contexts or especially protected (well-known) figures. This level corresponds to the third macro-strategy of justification discourse, the systematic distortion and the creation of a stereotyped image of one's opponent (Feindbild).

Level 4. Direct and open abuse of Jews. Such labels appeared - if at all - only in anonymous settings, in the memorial vigil, for example, or in complaint calls to the Austrian television network. Outside of such settings the perceived public sanctions against such statements would restrict their occurrence almost completely.

A qualitative text analysis, however, cannot restrict itself to the linguistic level alone. The way in which the types of content are presented and the patterns of argumentation which always appear are of equal significance. They contribute to the organization of the whole text and influence the use of certain linguistic devices. All macro-strategies fit into the patterns of justification identified above, from denial to reversal and counter-attack. Before we look at an example from 
a formal situation, we would like to present several typical forms of antisemitic language behaviour from varying contexts, all of them from the Waldheim electoral campaign of 1986 (de Cillia et al., 1987; Mitten et al., 1989).

\subsection{Predication and assertion}

Predication and assertion ascribe certain characteristics to people and groups of people. They are an important linguistic device for constructing a dichotomous world, which in turn functions to make judgments concerning 'insiders' and 'outsiders' or 'them' and 'us'. Predications can also assume the character of abuse, according to the context and explicitness of the four hierarchical levels. 'That whippersnapper, General Secretary Singer ... the private club with that bombastic name, World Jewish Congress ... the wheeling and dealing of the first president of the club, N. Goldmann, with the Arabs, the arch-enemy of the Jewish state' (Neue Kronen Zeitung (NKZ), 2 April 1986).

An excerpt quoted from a press conference of the Jewish Gemeinde in Vienna on 18 June 1986 is given below. It represents a collage of statements by spokespersons of the Austrian People's Party and serves as an example for the device of predication and the content of dishonesty: ${ }^{11}$

Untrustworthy and dishonourable methods. Dishonourable members of the World Jewish Congress. Untrustworthy - dishonourable and full of hate. Lies - deception and breaking promises - having no culture and simplistic and unfounded hate. The crying of the puppets of the World Jewish Congress motivated by hate and the need for admiration. Assassins. Mafia of slanderers. The epitome of baseness. Bribed witnesses. Methods of the mafia. Astoundingly stupid. Dirty self-aggrandisement campaigns. The habitual slanderer Singer.

\subsection{Allusions}

Allusions can be manifested in very different ways, for example, by means of citations, formal text construction, word choice, vagueness. All forms of allusion, however, share the characteristic that the connection between two contents is established implicitly rather than explicitly, and assumes previous knowledge on the part of the audience. Consequently, the responsibility for the interpretation is shifted onto the readers, who are believed to know the background of the insinuation (for example, 'dishonourable lot' [ehrlose Gesellen]).

In a letter which Karl Hödl, then vice-mayor of Linz, wrote on 12 May 1987 to Edgar Bronfman, the president of the World Jewish Congress, we find Christian antisemitism transmitted in the form of allusions. The writer of the letter makes a comparison between Bronfman as a Jew and Hödl as an 'Austrian, Christian and trained jurist', who must 'defend himself' against 'infamous attacks' - thus as a representative for Waldheim and all Austrians. The letter also contains an analogy between Waldheim's persecution by the World Jewish Congress (WJC) and the 
Jews' handing over of Jesus to the Romans. Finally, Hödl contrasts the revengeful Judaism of the Old Testament to a (forgiving) Christianity: 'An eye for an eye, a tooth for a tooth is not our European attitude. The basic Talmudic tendency to preach in the whole world is left up to them and theirs.' Similar analogies between the murder of Christ and the critique of Waldheim were found in a series of newspaper commentaries from 1986 and 1987 (e.g. Wodak et al., 1990; Wodak, 1990c, for example).

\subsection{Quotations (Discourse Representation)}

Quotations are an ever-recurring part of antisemitic language use. It is precisely this form of argumentation that has the appearance of being especially objective and rational. Quotations often enable a speaker or author to transport antisemitic prejudice without having to take responsibility for the statement. This is especially true of quotations by generally recognized authorities and, in the special case of antisemitic argumentation, of quotations by Jews, which are intended to reinforce the argument ('alibi Jews' such as Kreisky, Wiesenthal, etc.). In addition to deflecting authorial responsibility, quotations can be employed to cloak extreme antisemitism, while the quotations themselves can serve as allusions in the sense noted above. Decisive in this case is the specific way in which the statements of a third person are reported.

The term 'discourse representation' has been suggested for this basic aspect of media coverage (Hak, 1987). Not only the text that was actually expressed in the course of the coverage, but also the situation in the text at hand was almost always reported as well. Newspapers and the Austrian radio broadcasting company (ORF) made the most frequent use of this technique (cf. the example below), and the cases varied according to content and explicitness, and corresponded to the hierarchical levels $1-3 .{ }^{12}$

\section{Case Studies}

\subsection{Scenes from a Noonday Newes Programme - A Case Study}

The WJC held a press conference in New York on 25 March 1986. To a certain extent this constituted a turning-point in the Waldheim affair, especially because the entire country of Austria felt as if it had been attacked. Almost the entire programme (always a full hour from 12-1 o'clock every day except Sunday) was devoted to important aspects of the 'campaign' or to an alleged 'interference' in Austria's internal affairs and to commentaries on these subjects. In the evening news programme, a telephone interview with Waldheim was broadcast. A wide variety of views were obtained from important representatives of the political scene in Austria (Wodak, 1989b,c). The representatives of the WJC were the only ones who were not interviewed. A summary of press reports was read as was a commentary on a 'discussion about antisemitism', a formulation which is itself an euphemism. ${ }^{13}$ 


\subsection{The Situation on 25 March 1986 - What Really Happened?}

On 22 March 1986, the WJC published the CROWCASS listing (Central Registry of War Criminals and Security Suspects) which showed that after 1945 Waldheim had been sought by the US Army for alleged war crimes. This list also recorded (as it turned out mistakenly) that Waldheim had served in the counter-intelligence section (Abwehr) of Army Group E, which the press release of the WJC duly noted. At its press conference in New York three days later, 25 March, historian Robert Herzstein produced documents which showed that Waldheim had served in the military intelligence section (Ic) rather than the counter-intelligence section (Abwehr). ${ }^{14}$

At this latter press conference, neither Herzstein nor the WJC referred to Waldheim as 'an officer in the Abwehr', as the evidence Herzstein presented showed the CROWCASS listing to have been mistaken.

The reporting in the Austrian media on 25 March amalgamated these two press conferences (as well as an interview with WJC leaders which had been published on $24 \mathrm{March}$ ). The general tone was defensive, as though all Austrians had been implicated by the link between Waldheim and the Abwehr. This is the element that was focused on and distorted; the WJC, as well as Herzstein, were portrayed as having referred to Waldheim as an officer in the Abwehr (see also Mitten, 1991).

It thus became possible to defend oneself against an untrue accusation, and this in turn justified in advance any and all counter-attacks. At the same time, the 'accusations' and substantiated facts which the WJC or Herzstein actually raised were swept under the rug. With few exceptions, the Austrian media became passive supporters of the "campaign with "the campaign", i.e. the Waldheim propaganda line, merely by their (at least) sloppy handling of statements and documents.

\subsection{What Was Reported? - The Mittagsjournal on 25 March 1986}

The news programme itself was introduced as follows:

The discussion about the past of the ÖVP's presidential candidate, Kurt Waldheim, has reached a new climax since Sunday. The announcement by WJC representatives to present further serious accusations against the former UN General Secretary at a press conference which will take place this afternoon in New York has given a new twist to the discussion. It certainly has to do with claims about Waldheim's involvements, but the discussion is also already concerned with the extent to which the WJC is interfering in Austria's internal affairs. For the former chancellor, Kreisky, there are indications of this direction. In a Morgenjournal interview today, Kreisky expressed his disapproval of the WJC General Secretary's statements and also defended Kurt Waldheim against such accusations.

The introductory presentation itself reveals patterns of interpretation and argumentation. Nearly an entire new programme was devoted to a press 
conference that had not yet taken place and to a discussion of 'accusations' which had not yet been made, providing Austrian politicians with the opportunity to exonerate themselves, as it were, pre-emptively. The moderator trivialized the 'discussion' and 'claims about Waldheim's involvement' in possibly being privy to information regarding war crimes in the Balkans, and with Kreisky's help he called listeners' attention to the change of 'interference in Austria's internal affairs' (we-discourse). The factitive portrayal of the WJC's ostensible (and arguably invented) 'accusations' accords it a certain status (discourse representation as a micro-strategy), while it is unclear what the WJC actually claimed (vagueness). In the broadcast, Waldheim was referred to by means of (positive) descriptive expressions (i.e. presidential candidate and especially former General Secretary of the UN) which tended to reflect the emphases of his campaign publicity. In contrast, the WJC was referred to by name three times in this short text, and these and other examples show how this name itself permits and can even trigger prejudiced associations such as world conspiracy, promoting the introduction of such strategies as black and white depiction or personalization and defamation.

The former Austrian chancellor, Bruno Kreisky, was the first Austrian politician to be quoted:

Kreisky: First of all, I knew nothing about any of the things being asserted about Dr Waldheim as a person. However, if I had known, I would certainly not have withheld my recommendation in this case uh uh, because it all happened a long, long time ago. And he was a young man ... But that is not what it is all about at all. The point is, that certain groups, albeit very small ones, are interfering in the Austrian campaign ... with both candidates in an improper way in my opinion. I am not prepared to tolerate this. But these groups have been fighting me for decades. ...

Interviewer: Dr Kreisky, your party argues that, it is said, that to a certain extent he admits that he was there, that he did not say that from the beginning. How do you see this?

Kreisky: Yes, well, that is none of my business. I don't want to have anything to do with it. Oh, it is all very unpleasant, and I don't want to have anything to do with it.

Kreisky justified and defended Waldheim as opposed to 'certain circles' [gewisse Kreise] by employing the strategies of rationalization and trivialization (both micro-strategies of the macro-strategy of mitigation) and also moved onto the next macro-strategy, i.e. 'making a clear break with the past'. On the other hand, Kreisky resorted to counter-attack, utilizing a group of macro-strategies in the discourse of justification: the disclosures have nothing to do with Waldheim's past - thus, every right to 'debate the past' is denied; the more important issue is that 'certain circles' (cliché), although small, have been persecuting Kreisky for years (contents of victim-victimizer reversal and world conspiracy, expressed as allusions and distortions). Kreisky thereby directed the WJC attacks to himself and to a certain extent then had to defend himself against them. Distortion and unwarranted inferences actively contribute to the Feindbild of the WJC. This discourse is not new, but is a way, typical of Austria, of dealing with the Nazi past, which Kreisky had previously used in connection with Friedrich Peter in $1975 .{ }^{15}$ 
Kreisky serves a three-fold purpose here: as the 'alibi Jew' (his words thus carry more weight), as former chancellor and socialist (even the opposition stands by Waldheim), and finally, as a worldly wise and world-travelled diplomat (he can certainly estimate Waldheim's worth). In responding to the journalist's unpleasant and persistent questions, Kreisky employs a further macro-strategy of justification, already mentioned above: he simply cuts off the discussion!

Ivan Hacker, president of the religious community, is interviewed next:

Moderator: . . The Israelite religious community [Gemeinde] felt compelled last night to initiate a discussion, which amounted to taking a stand and expressing great concern and a warning about the sentiments that are being unleashed. [The idea] that the making public of documents [should] be characterized at once as slander and a smear campaign was disputed....

Hacker: We reject any linguistic dictums that at once nullify the publication of documents about Dr Kurt Waldheim's past with labels such as slander and smear campaign. By showing contempt for the exposers and making the Jews the scapegoat. This personal appeal to suppressed emotions on the part of certain ÖVP functionaries is what we condemn the most. Because it gives the Brownshirts and antisemites a new claim to legitimacy and reveals shameful political calculations.

Interviewer: ... Are you referring specifically to Dr Graff?

Hacker: Certainly, Graff .... But we condemn the tendency of individual SPÖ functionaries just as much for going along with this dismissal of the past and distancing themselves from disclosures about it. The same calculated thinking is employed here to get the same votes. We deeply regret the apparently widespread view in Austria that the appeal to Hitler-Germany and to doing one's duty [i.e. in the German Wehrmacht], as it is put, produces a stronger solidarity than does a declaration for a new democratic Austria....

Interviewer: . . . Does this remark [i.e. doing one's duty] refer to Dr Waldheim?

Hacker. Him too .... I am referring to everyone who says that, not only Waldheim ....

Interviewer: ... How do you view uh statements of individual WJC functionaries .... That can't be very pleasant for you as die president of the Israelite religious community in Austria?

Hacker: It's not at all pleasant. But the Jewish world organization is a totally . . . democratic, independent organization. Therefore, he [Israel Singer, general secretary of the WJC] must take responsibility for whatever he has said ....

Interviewer: In any case, you don't see it as the WJC interfering in the Austrian presidential election?

Hacker: Interference. One can view it in different ways. I see it as the WJC tracing the history of a certain General Secretary of the UN ....

Interviewer: . . . How can one stop this escalation of emotions?

Hacker: If I could answer this question, I would not be sitting here at this table, but would be one of the leading politicians in the world.

Thus, after Kreisky, a 'Jewish fellow citizen' [ jüdischer Mitbürger] had a chance to speak. Hacker was upset and made a point of the 'sentiments of the Austrians'; he accused both parties of trivialization and of playing a dangerous game; he saw through this specific way of dealing with the past. The interviewer, however, did not pursue these extremely pointed statements or the opposing discourse, but rather short-circuited them: the statements of individual WJC functionaries 
are presented as interference in the Austrian election campaign. Both topic and level are changed, and Hacker is no longer able to find the generally held, analytic first level of argumentation.

This opposing view therefore remains isolated and personalized and mitigated by Kreisky in his role as 'alibi Jew'. Following Hacker, the programme quoted the view of one of the main architects of the "campaign within the "campaign", Michael Graff. It was introduced as follows:

General Secretary of the ÖVP, Michael Graff, who, according to Hacker, had appealed personally to suppressed emotions, again stated his views regarding the discussion about Waldheim and the current state of the presidential election campaign. ...

The presentation contained an interpretative pattern: the accusation against Graff is personalized. 'According to Hacker', there are latent threats - this mitigates the content and trivializes it. In reality, the discussion was less about Waldheim personally than about Waldheim's past and his way of dealing with it. This way of describing it alters and distorts the content of the debate.

Graff first attacked the SPÖ and suggested that lying behind the 'infamous slander campaign' are economic-political reasons and an attempt to distract voters' attention away from the governing party.

The slander campaign, which has been sparked in the vicinity of the Chancellor and has naturally spread like wildfire, is out of the control of those who set it; it is on its way and the damage it will do to Austria both from the inside and the outside is unforeseeable.

Two things are noticeable here: first, the affective use of language and the abundance of metaphors, which paint an especially threatening picture. Second, the victim-victimizer reversal and we-discourse. Austria (in effect Waldheim and Waldheim supporters) is accordingly the victim of a 'slander campaign', and the instigators, whoever they may be, are accountable for any damage. On this occasion Graff still placed the original instigators in Austria. Then, however, he turned to attack the WJC, whose charges he describes as 'indescribable' and 'much exaggerated'.

Moderator: He [Graff] is firmly convinced that Waldheim had nothing to do with war crimes. And the only purpose of the documents which are announced for this afternoon in New York is to contribute to the mud-slinging. Graff responded as follows to the Israelite Gemeinde's warning about antisemitic information, without knowing the details of their position.

Graff. It is exactly this type of discussion that worries me so much. I said in my interview on the Morgenjournal that I am very concerned about the behaviour of individual representatives of the World Jewish Congress, because it is precisely such exaggerated attacks that can unleash emotions in this country, and no one wants 
this ... Of course we must take the statements of our Jewish fellow citizens seriously. And I deeply regret that because of this unqualified campaign, which in the meantime uh uh has also been criticized by Kreisky, graves have been dug up. I uh find that the instigators of this campaign have themselves to blame for this. And they will have to live with this burden.

After this Graff called on the government to defend Waldheim and to investigate who had leaked the documents in this case.

Graff appeared to respond to Hacker's accusation, but merely repeated his statement, thereby getting the chance to justify himself and also to have the last word. Graffs reference to Kreisky, moreover, completely trivialized Hacker's statement. The affective use of language is especially noticeable in the labelling of the WJC and the alleged 'campaign', which could engender any number of possible associations.

The macro-strategy employed by Graff consists chiefly in ignoring the content of the accusations made by the WJC. Instead, he defended himself against accusations which the WJC had not made (war criminal, etc.) or against those which he could not have known about (distortion and preemptive justification). He could thus turn the tables: he was given free reign to attack the victims who are themselves to blame for the emergence of antisemitic sentiments because of their exaggerated accusations, thus also to blame for the suffering of Austrian 'Jewish fellow-citizens' (differentiating between 'good' and 'bad' Jews). His remarks that Austria must defend itself against these attacks, and the government must protect the individual Waldheim, rest on the assumption that Austria as a whole has been attacked, but is made credible only by means of systematic distortions, manoeuvres of we-discourse and a scapegoat strategy. Indeed, the contents of the actual accusations and the debate about the past, etc., were intentionally distorted. Hacker's opposing discourse was weakened and the discourse of justification won out, as it was additionally strengthened by the presentation as well as by the time and placement allotted to it in the 'Journal'.

The next sequence in the programme is a summary of opinions on the matter in Austrian newspapers. Then Mario Ferrari-Brunnenfeld, an under-secretary in the ministry of health and member of the FPÖ (Freedom Party of Austria), was asked for his views on the matter:

In answer to the question of why the third parliamentary party has kept itself out of the debate surrounding Waldheim, the current Secretary of State said in the Ministry of Health. ...

Ferrari-Brunnenfeld: We will not interfere in the dispute about the presidential candidates in the future either. Although we very much regret the form this dispute has taken on. And that foreign countries are beginning to interfere in the internal affairs of Austria at this particular time, because of the awkward handling of the election campaign. Uh then I believe that uh that uh the problem that we have regarding this national uh presidential election, we do have one uh, that uh a presidential candidate does not own up to his past, has provided the starting-point of these discussions. ... 
In answer to the question of whether he also had misgivings about the possibility of antisemitism, Ferrari-Brunnenfeld replied:

I think the Israelite Gemeinde would have been smarter to keep out of this discussion. And secondly, I don't believe that it's a racial issue, but rather that the Jewish organizations have themselves intervened in a discussion with the motto 'Stop thief!' suddenly entering the forum of public discussion, so to speak. I mean that as far as I know - and I do get around - there's no sign of anything like neo-antisemitism. But I believe that the Jewish organizations are sparing nothing to make it a point of discussion, and a lot of neutral citizens are naturally asking what's going on? Who asked them? Who asked for their opinion? It's purely an internal matter of Austria. Interviewer: What you're saying then is that the Jewish organizations themselves are to blame if there is a new discussion about antisemitism?

Ferrari-Brunnenfeld: As grotesque as it sounds, that's how it looks to me ....

Ferrari-Brunnenfeld thus also defined the WJC's role as unjustified interference from 'abroad' in 'internal things of Austria' (we-discourse), but considered the main problem to be the way Waldheim had dealt with his past. He accused Waldheim of 'not owning up to' his career in the German Wehrmacht, a sentiment probably designed to address a specific constituency in his own party, the (German) 'national' wing.

When antisemitism was introduced, Ferrari-Brunnenfeld shifted into dominant 'campaign discourse' mode very smoothly. He first attempted to trivialize the problem, and then accused the 'Jewish organizations' of trying to make themselves look good. Then he reverts to the victim-victimizer reversal: the Jews are themselves to blame for their misfortune!

The press conference of the WJC took place as scheduled that afternoon (CET). At this conference no mention was made of Waldheim in connection with the Abwehr. On the evening news programme Abendjournal Waldheim was interviewed via telephone about the allegations the WJC had ostensibly made about him:

Interviewer: You've heard the report from our New York correspondent about the press conference the World Jewish Congress gave today. Uh we can uh summarize uh these accusation approximately like this: it can be proven that you were a Nazi; you lied for forty years; you knew about and personally took part in partisan activities - all are accusations that are diametrically opposed to the positions you have previously held.

Waldheim: Yes, I categorically deny these accusations. Uh, the former Chancellor Kreisky has also already explained that these accusations by the uh World Jewish Congress have to do with, and I quote, with 'monstrous baseness' [ungeheure Niedertracht].

Following this exchange, Waldheim offered a lengthy justification based on the themes of 'doing one's duty' and having served in the Wehrmacht, 'just like hundreds of thousands of other Austrians'. Kreisky thus serves as Waldheim's 'alibi' Jew, and by quoting Kreisky, Waldheim can shift the responsibility for the defamation away from himself. Waldheim's own 'carelessness' about his 
past is pursued by neither Waldheim nor any of the other politicians who were quoted. The description of Waldheim as an officer in the Abwehr (contained in the CROWCASS listing, and reported - once - by the WJC), is central to his justification. He can legitimately dismiss this one accusation; all others are thereby similarly dismissed or simply ignored. Towards the end of the interview Waldheim is asked:

Dr Waldheim, would it be correct to summarize your statements in the following way: there is nothing correct, nothing true in what the World Jewish Congress publicized in New York today?

Waldheim: I wouldn't say that. Well, the fact, that I was seen uh there and was present there, is true....

After this vague and euphemistic explanation, Waldheim again very strongly denies accusations, especially those that were never made.

One last question, Dr Waldheim: You continue to maintain that you knew nothing about the deportation of Jews, specifically about those from Thessaloniki?

Waldheim: I continue to maintain this. There is no reason to change my statement.

The interviewer does not address the principal questions raised by the WJC, but is railroaded into discussing details considered (by Waldheim) to be relevant. In this way, Waldheim's justification is the absolute and uncontested conclusion for the official ORF news on this day.

\section{Conclusions}

All the politicians interviewed in these two radio news programmes employed similar strategies: trivializations, denial and finally cutting off the discussion when the discussion dealt with Austria's Nazi past; distortion, defamation and preemptive defence against charges still unknown when the discussion dealt with the WJC. The introductory passages and interviewers' questions reinforced this discourse. The order of speakers interviewed in the programme, i.e. Hacker's inconspicuous position between Kreisky and Graff, made the opposing arguments relatively ineffective. The diversion and avoidance strategies were successful: the discussion no longer had to do with Waldheim's past, but rather with Waldheim as Austria. It was not about post-war Austria and antisemitism, but about the WJC, their accusations which, in addition, had been systematically distorted.

The scapegoat strategy, 'Iudeus ex machina' (see Wodak, 1989a) and the construction of this Feindbild can be clearly seen in actu in this news broadcast. The premiss is we-discourse, which all the politicians without exception used. One defends oneself against foreign countries and their interference in Austria's internal affairs. In this way the criticism of Waldheim's dealings with his past was transformed into a plot against Austria contrived by vengeful Jews seeking admiration. When such a reality is constructed by influential politicians in a public forum such as a news broadcast, it is not surprising that antisemitism is expressed 
much more explicitly in other contexts (such as the memorial vigil).

Did 1986 change anything? Has the antisemitic language use become more obvious? Antisemitic prejudices are ubiquitous in Austria. Since 1986, however, some taboos have fallen away in certain public realms, especially in the media. Although the more subtle expressions of prejudice are usual in such formal contexts, certain persons are entitled to employ cruder or more blatant forms in such contexts as well, conjuring up images of an enemy by reverting at the same time to a mystified past and to Austria's sham existence. The connection between justification and counter-attack, between guilt and the construction of a Feindbild, is ineluctable.

\section{Acknowledgements}

It would like to thank Michael Agar, Gerhard Botz, Teun van Dijk and Richard Mitten for their very useful comments and criticism on earlier drafts of this article, as well as Ardith Meier and Richard Mitten for their help in translating and editing this paper. The details of the whole study are published in Wodak et al. (1990).

\section{Notes}

1. Interview with the Shanghai Echo, quoted in Der Neue Weg, no. 10, the beginning of June 1947, p. 11.

2. 'Comment expliquez-vous que la presse internationale ait été aussi largement critique envers vous? (II s'emporte.) Mais parce qu'elle est dominée par le Congrès juif mondial, c'est bien connu!' Interview with Claire Trean, le Monde, 3 May 1986.

3. In Austria, religions have institutions recognized in law which record the number of members. The 'Israelitische Kultusgemeinde' is the official representative of Austrian Jews. There is no Anglo-American equivalent, and the term 'Jewish Community' is conventionally not restricted to those who officially declare themselves Jews on religious grounds. For this paper, when this particular Jewish institution in Austria is meant, the German Gemeinde is employed.

4. Two case studies which were part of the project 'Sprache und Vorurteil' (Language and Prejudice) were able to shed some light on the Waldheim Affair and on an earlier dispute between Simon Wiesenthal, then Austrian Chancellor Bruno Kreisky, and the then head of the Austrian Freedom Party (FPÖ) Friedrich Peter. Both affairs were examined qualitatively in public and semi-formal settings. The whole register of the forms and contents of antisemitic prejudice could be identified in both. This register appears continuous: an appropriate prejudice is sought and found according to situation. The project report (Wodak et al., 1990; Projektteam 'Sprache und Vorurteil', 1989) includes all the data as well as the theoretical and methodological approaches employed in the study.

5. Questionnaires and standardized interviews, and telephone surveys even more so, have serious limitations in prejudice research, since especially in the area of taboos it is almost impossible to obtain opinions and attitudes; therefore, the studies differ from each other. Hilde Weiss' questionnaire appears to be sophisticated and she reaches 
several important conclusions. Other opinion surveys already fail in their formulation of the questions (cf. in detail regarding this, Projektteam 'Sprache und Vorurteil', 1989).

6. The Moscow declaration, issued by the foreign ministers of the US, Great Britain and the Soviet Union in October, 1943, included the statement that Austria 'was the first victim of Hitler's typical policy of aggression'.

7. Between 1945 to 1949 , former members of what were termed 'more incriminated' Nazi organizations were disenfranchized as a part of the de-Nazification policy. In the 1949 elections, the Union of Independents, which reorganized the (German) 'nationally inclined', captured 20 seats. The Freedom Party [Freiheitliche Partei Österreichs] was formed in 1954 out of the Union of Independents. Friedrich Peter was chairman of the FPÖ in 1975. For background on this 'affair' see van Amerongen (1977); Wodak et al. (1990).

8. Kreisky's own conception of nationhood derives from the Austrian Socialist theorist Otto Bauer. Bauer's criterion for a nation was that it be a 'community of fate' (Schicksalsgemeinschaft). Neither Bauer, who died in 1938, nor Kreisky would concede that the Jews are a nation. This in itself is a legitimate position to defend, and Kreisky's pejorative and contemptuous aside probably referred to the difficulty of the Jews conforming to his (unspecified) criteria of nationhood. This, however, in no way mitigates the charge of irresponsibility, and, in the context, would easily be seen as pandering to the anti-Wiesenthal hostilities of the FPÖ voters.

9. One example from our data illustrates this point. The then leader of the People's Party, Alois Mock, said the following in an interview on Zeit im Bild, a TV-news broadcast on 5 June 1986: 'That guy Singer travels around the world and, aided by the pressure of the international media, suddenly demands that one look at documents from the archives that have been available for forty years. Many say okay, we can take a look at them. We are not going to risk the pressure and the argument with the men who were even able to place the large international media at their disposal in an unprecedented manhunt [Menschenhatz]' (Zeit im Bild, 5 June 1986).

10. For the entire range of these, of which only a few representative samples can be offered here, see Projektteam (1989). Regarding the concept of 'strategy', see ibid., Ch. 7.2 (cf. also Lutz and Wodak, 1987).

11. The entire interview illustrates numerous strategies of justification (see Wodak et al., 1990).

12. For other examples of such linguistic realizations, especially from the semi-public and anonymous spheres, see Projektteam (1989). We have limited ourselves here to those patterns which are actually found in the example passage. The hierarchy of explicitness mentioned above contains the full range of possible antisemitic forms of expression.

13. The complete context, analysis and text can be found in Wodak et al. (1990). Here, the most important politicians are presented as well as the supplementary comments made by the moderator. The Austrian radio station is a state monopoly (ORF). This example shows better than most others how reality is distorted and how the Feindbild Jud was constructed.

14. For the purpose of this article it is sufficient to note his service. The Abwehr section of Army Group E could have brought Waldheim ceteris paribus closer to activities judged criminal by the Military Tribunal at Nuremberg than would have his duties in the military intelligence. For details on this point, see Kurz et al. (1988).

15. See Wodak et al. (1990). 


\section{References}

Adorno, T.W. (1973) Studien zum autoritären Charakter. Frankfurt/Main: Suhrkamp. Allport, G.W. (1987) The Nature of Prejudice. Reading, MA: Addison-Wesley. van Amerongen, M. (1977) Kreisky und seine unbewältigte Vergangenheit. Graz: Styria. Botz, G. (1987) 'Stufen der Ausgliederung der Juden aus der Gesellschaft. Die österreichischen Juden vom "Anschluß” zum "Holocaust"' Zeitgeschichte 9/10 June/ July: 359-78.

Bunzl, J. and Marin, B. (1983) Antisemitismus in Österreich. Innsbruck: Inn-Verlag. De Cillia, R., Mitten, R. and Wodak, R. (1987) 'Von der Kunst, antisemitisch zu sein', in Katalog zur Ausstellung Heilige Gemeinde Wien. Die Sammlung Max Berger im historischen Museum der Stadt Wien, pp. 94-107. Wien: Historisches Museum.

Erdheim, M. (1984) Die gesellschaftliche Produktion des Unbewußten. Frankfurt/Main: Suhrkamp.

Gruber, H. and de Cillia, R. (1989) 'Menschenfresser aller Länder vereinigt euch! Antisemitische Stereotype in den österreichischen Medien seit 1986', Journal für Sozialforschung 29(2): 215-43.

Hak, T. (1987) 'Discourse Representation in Media Discourse'. Manuscript. Amsterdam.

Heinsohn, G. (1988) Was ist Antisemitismus? Der Ursprung von Monotheismus und Judenhaß Warum Antizionismus? Frankfurt/Main: Scarabäus bei Eichborn.

Kienzl, H. and Gehmacher, E., eds (1987) 'Antisemitismus in Österreich. Eine Studie der österreichischen demoskopischen Institute.' Wien: Nationalbank.

Knight, R., ed. (1988) 'Ich bin dafür, die Sache in die Länge zu ziehen'. Die Wortprotokolle der österreichischen Bundesregierung von 1945 bis 1952 über die Entschädigung der Juden. Frankfurt/Main: Athenäum.

Kurz, H., Collins, J., Vanwelkenhuysen, J., Fleming, G., Fleischer, H., Wallach, J. and Messerschmidt, M. (1988) Der Bericht der internationalen Historikerkommission 8 February 1988, supplement to Profil, 15 February 1988.

Lutz, B. and Wodak, R. (1987) Information für Informierte. Linguistische Studien zu Verständlichkeit und Verstehen von Hörfunknachrichten. Wien: Akademie der Wissenschaften.

Mitten, R. (1991) The Politics of Antisemitic Prejudice. The Waldheim Phenomenon in Austria. Boulder, CO: West View Press (in press).

Mitten, R., Wodak, R. and de Cillia, R. (1989) 'Sprechen Sie antisemitisch?', Sprachreport 2: 3-11.

Poliakov, L. (1987) Geschichte des Antisemitismus. Emanzipation und Rassenwahn. Worms: Jüdischer Verlag Athenäum.

Projektteam 'Sprache und Vorurteil' (1989) “'Wir sind alle unschuldige Täter”. Studien zum antisemitischen Diskurs im Nachkriegsösterreich', 2 vols, final report. Wien: Institut für Sprachwissenschaft.

Pulzer, P.G. (1966) Die Entstehung des politischen Antisemitismus in Deutschland und Österreich 1867-1914. Stuttgart: Gütersloh.

Stern, F. (1989) 'The Whitewashing of the Yellow Badge: Antisemitism and Philosemitism in West Germany'. Dissertation, Tel Aviv.

Weiss, H. (1987) Antisemitische Vorurteile in Österreich. Wien: Braumüller.

Welzig, E. (1985) Die 68er. Karrieren einer rebellischen Generation. Wien-Köln- Graz: Böhlau.

Wodak, R. (1989a) 'Iudeus ex Machina', Grazer Linguistische Studien 32: 153-80.

Wodak, R. (1989b) '1968 - The Power of Political Jargon: A Club-2 Discussion', in R. Wodak, (ed.) Language, Power and Ideology, pp. 137-65. Amsterdam: Benjamins.

Wodak, R. ed. (1989c) Language, Power and Ideology, Amsterdam: Benjamins.

Wodak, R. (1990a) 'Some of My Best Friends are Jewish', Patterns of Prejudice (in press). 
Wodak, R. (1990b) 'Alles schonmal da gewesen? Gespräche bei der Mahnwache', in A. Holl (ed.) Aus Menschen werden Monster (in press).

Wodak, R. (1990c) 'Opfer der Opfer? Der "alltägliche Antisemitismus" in Österreich erste qualitative soziolinguistische Überlegungen', pp. 292-319 in W. Bergmann and R. Erb (eds) Antisemitismus in der politischen Kultur nach 1945. Opladen: Westdeutscher Verlag.

Wodak, R. and de Cillia, R. (1988) Sprache und Antisemitismus, vol. 3: Ausstellungskatalog. Wien: Mitteilungen des Instituts für Wissenschaft und Kunst.

Wodak, R., Nowak, P., Pelikan, J., Gruber, H., de Cillia, R. and Mitten, R. (1990) 'Wir sind alle unschuldige Täter!', Diskurshistorische Studien zum Nachkriegsantisemitismus. Frankfurt/Main: Suhrkamp. 